\title{
Tweeting in Disaster Area: An Analysis of Tweets during 2016 Major Floods in Indonesia
}

\author{
Anang Dwi Santoso ${ }^{1}$
}

\begin{abstract}
Social media allows people in the disaster area to communicate disaster information, to the people outside the disaster area, more quickly and accurately. Unfortunately, there are limited researches that examine the use of Twitter by people in the disaster sites. This study aims to explore the use of Twitter by users in the disaster-affected areas. We use the feature of twitter geolocation, to separate information from inside and outside the disaster site. This research gives depiction about communication behavior of people in the affected disaster area, through social media. The result showed that people in disaster location use twitter to give first-hand report, coordinate rescue effort, provide help and express grief. In addition, by focusing on the affected area, Twitter used by lay people is usually found rather than other users. From the segment of time, the researcher finds a number of tweets that will increase each day. Users will share more information the days after rather, than the day of disaster. In practical term, this research explores the used of social media by the victims of disaster, which can encourage effective communication to people or group outside the location; theoretically, this research gives more detail understanding about shared information from the people in the disaster place.
\end{abstract}

\section{Keywords:}

disaster communication; disaster area; geolocation; twitter.

\section{Introduction}

Disaster communication is one of the most important elements in disaster management. Effective communication will decrease the impact of the disaster (Rodríguez et al., 2007; Takahashi, Tandoc and Carmichael, 2015). As a consequence, developing effective disaster communication is a priority. The functions of communication in the disaster are increasing the alertness, endurance of both the individual and the community, assuaging distress and maladaptive behaviors, promoting the health mechanism and recovery, increasing the society's awareness about what happens and connecting the people (Houston, 2012).

The channel which is often used in disaster communication is mass (Rodríguez et al., 2007). The appearance of social media, makes mass media categorized as traditional media. In general, traditional media in disaster communication is used to send warning messages, and report about the disaster situation (Houston et al., 2014). The messages can then influence behavior, knowledge, and attitude of the receivers. Unfortunately, traditional media tends to do one-way communication. Meanwhile, two ways disaster communication become one of the most important things in disaster management, because individual is not a passive object. An individual can produce and eliminate the information (Takahashi, Tandoc and Carmichael, 2015). Besides, the role of traditional media in disaster communication has not been clear (Wahlberg

\footnotetext{
${ }^{1}$ Department of Public Policy and Management, Faculty of Social and Political Sciences, Universitas Gadjah Mada. Email: anang.dwi.santoso@mail.ugm.ac.id
} 
and Lennart, 2014). Shklovski, Palen, \& Sutton (2008) adds that disaster also causes the damage of communication infrastructure and information, so that it decreases the availability of information related to the disaster.

The emergence of social media pledges the better disaster communication. An individual can communicate two ways to the society about the disaster (Fraustino, Liu, and Yan, 2012). Alexander (2014) identifies seven benefits of social media in disaster, such as giving people the opportunity to give moral and material supports, monitoring the situation of the disaster, integrating social media data into disaster management, collaborating to help disaster victims, making social cohesion and promoting therapeutic initiatives, fundraising and research.

Social media in disaster communication is able to fulfill deficiency of traditional media, especially in the function, as the platform gives up-to-date information (Takahashi, Tandoc and Carmichael, 2015). People who are in the disaster area can communicate current condition to other people outside the disaster area. Starbird \& Palen (2010) find that people outside the disaster location use more social media rather than the people in the disaster area. We believe this makes most of the researchers about social media usage in disaster management, to focus on the usage of social media without regarding where the information is from (Smith, 2010; Acar and Muraki, 2011; Muralidharan, Dillistone and Shin, 2011; Bruns et al., 2012; Murthy and Longwell, 2013). Thus, the research is needed to observe the people's behaviors in the disaster area through social media.

This research aimed to explore the use of social media in the disaster area. This research used geolocation twitter feature to obtain tweets from a specific area. This research is useful in practice and theoretic. In practical term, it explores the used of social media by the victims of the disaster, which encourages effective communication to the people or group outside the location. Theoretically, this research gives more detail understanding about the shared information, from the people in the disaster location.

For more detail, this research will categorize the use of social media by impacted disaster people. This research will be group into a framework, which is made by (Takahashi, Tandoc and Carmichael, 2015). This research also groups the user into some groups, such as news organization, individual, government, $\mathrm{NGO}$, and others. Lastly, this research will also observe whether there is communication pattern during or after the disaster happened.

\section{Related Work and the Development of Research Question}

Social media is one of the platforms which enable two ways communication. People in the disaster location, can give up-todate information about the disaster condition to people outside the location (Takahashi, Tandoc and Carmichael, 2015). There are some researchers which attempt to explore the different of using social media outside affected area and inside the area, which are Binder, 2012; Miyabe, Miura, \& Aramaki (2012); Starbird \& Palen, (2010); Takahashi et al., (2015); Vieweg, Hughes, Starbird, \& Palen, (2010).

Starbird \& Palen, (2010) explored Twitter usage as a disaster communication media, which happened in spring 2009. They are sure that Twitter is the right media to learn communication during the disaster, because this media is adopted fast and large. This research highlights the used of retweet by people outside and in the disaster area. In an emergency situation, local users tend to use retweet feature to inform the condition of surrounding environment. People who are outside the disaster location tend to use retweet feature to share obtained information from journalist accounts. In addition, local media, and disaster management agents, have 
still become two organizations, who have an important role in sharing disaster information.

Study of Miyabe et al., (2012) observed Twitter usage after earthquake 2011 in Japan. Tweets were collected just after the disaster happened. The researcher analyzed, and grouped into various factors, in which location was one of the factors. The result of that research showed that people in the disaster area tent to use Twitter to communicate with other users, through a reply-based tweet. In contrast, users outside the affected area tried to share the disaster information by using retweet.

Furthermore, Vieweg et al., (2010) analyzed microblog post in Oklahoma Grassfires, which happened in April 2009, and the Red River Floods which happened in March and April 2009. The research focused on the disaster communication by people who were in the area of the disaster. The result of that research showed that Twitter users tend to share the same information such as evacuation, sheltering, animal management and damage and injury report.

The last is Takahashi et al., (2015) who tried to give depiction about the tweet, which was shared by the users in and outside Philippines during Typhoon Haiyan. The result of that research showed that people who were in Philippines tend to share the information with secondhand reporting type, coordinating relief and memorializing whereas people outside Philippines tend to share information about secondhand reporting, memorializing and coordinating relief. Both of the types are different in the percentage.

Geographic aspect becomes an important aspect to observe the behavior of Twitter users when the disaster happens (Takahashi, Tandoc and Carmichael, 2015). Unfortunately, four findings above have different results related to Twitter users in the disaster area, using Twitter to communicate disaster. It then encourages this research to try to analyze Twitter usage in a disaster communication, with proposing three questions as follow 1) What is information which is shared by Twitter users in disaster location?, 2) Who are Twitter users in disaster location?, 3): Is there any different information which is shared by Twitter users during and after the disaster?

\section{Methods}

This research consists of several stages. The first stage in this study is data collection. We employ scrapping technic from the site of https://twitter.com/search-advanced to gather the data. The scrapping process is done by utilizing Python Tweepy libraries http://tweepy. readthedocs.io/en/v3.5.0/api.html\#tweepy-apitwitter-api-wrapper and Twitter API. Scrapping tweets are automatically done to retrieve tweet data with a specified length of time. Before the scrapping process begins, this system will check the consumer key and access token, so that the system can retrieve data from Twitter, if the token data was listed in the Twitter system. The system will then store the tweet data into the database. Tweet data will automatically be saved in the MySQL database and exported to a .csv file.

Scrapping from the site of https://twitter. com/search-advanced allows the researcher to gather the data in the specific area. Twitter introduces geolocation feature to collect the tweet in particular area. We then used geolocation feature to give depiction more detail about shared information during and after the disaster. We then do a content analysis of the content shared on Twitter. By using the case of Flood in Garut Regency, Sumedang Regency, and Bandung City, we managed to collect 1083 tweets around the disaster area. To launch our search, using some keywords like banjir (flood), bantuan (help), bencana (disaster), korban (victim), \#banjir (\#flood), \#prayforSumedang \#prayforBandung and \#prayfor Garut. The system we created, allows the system to collect data in the form of date, time, account, tweet, bio, and location. In addition, 
Table 1.

Data Collecting Profile

\begin{tabular}{|c|c|c|c|c|c|}
\hline No & Location & Disaster & Keyword & Date & $\begin{array}{c}\text { Number of tweet } \\
\text { collected }\end{array}$ \\
\hline 1 & Garut & Banjir & Banjir, bantuan, bencana, & 21-29 September 2016 & 480 \\
\hline 2 & Sumedang & Banjir & korban, \#banjir \#prayfor & 21-27 September 2016 & 120 \\
\hline 3 & Bandung & Banjir & & 24-27 October 2016 & 370 \\
\hline
\end{tabular}

Source: Research results

Table 2.

Social Media Usage during The Disaster

\begin{tabular}{|c|c|}
\hline Category & Description \\
\hline $\begin{array}{l}\text { Situation report disaster from } \\
\text { personal perspective }\end{array}$ & $\begin{array}{l}\text { Providing and receiving information of alertness and disaster warning and inform } \\
\text { other people about condition and location and disaster from a personal perspective. }\end{array}$ \\
\hline Secondhand reporting & $\begin{array}{l}\text { Including disaster detection, documentation about what happened and sending } \\
\text { disaster information }\end{array}$ \\
\hline Request for help & Request for help during and after the disaster \\
\hline Coordination of rescue effort & $\begin{array}{l}\text { Increasing disaster awareness, donating and receiving donation, identifying the way } \\
\text { to help or become volunteer and providing disaster information }\end{array}$ \\
\hline Providing mental cancelling & Providing and receiving the help of health and mental recovery \\
\hline Criticizing the government & Discussing responsibility of government in managing the disaster \\
\hline $\begin{array}{l}\text { Express the hope and } \\
\text { sympathy }\end{array}$ & Expressing the emotion, care, hope and remembering the victim \\
\hline $\begin{array}{l}\text { Discussing the cause of } \\
\text { disaster }\end{array}$ & Including scientific discussion, religion and other causes \\
\hline $\begin{array}{l}\text { (Re)connect community } \\
\text { members }\end{array}$ & Discussing about how the process to place the people after disaster \\
\hline
\end{tabular}

Source: Research results

we are assisted by Microsoft Excel 2013 to group the data.

In more detail, 480 tweets from this research were gathered from the floods in Garut Regency, from 21 September to 29 September 2017. Furthermore, in the case of the floods in Sumedang District, we found 120 tweets from the date of 21-27 September 2017. Finally, in Bandung, we gathered 370 from 24-27 October 2017.

The collected tweet is then categorized into categories created by Takahashi et al. (2014). The Categories include Situation report disaster, from the personal perspective, secondhand reporting, request for help, coordination of rescue effort, providing mental cancelling, criticizing the government, express the hope and sympathy, discussing the cause of the disaster, and (re)connect community members. The detailed information of each category can be seen in Table 2 . The data then presented into the form of percentage to find out what information is shared most.

By using twitter biodata, we categorize users into several categories, such as community, government, media, celebrities, and journalists. This category is used to see the actors who use the most social media in the disaster area. We present twitter user data in a percentage form. It is intended to see the significance of the number of actors and the categories of information they share.

In addition, the authors also focus on the information shared by the community in the disaster location. Researchers remove tweets from government, media, celebrities, and journalists. The purpose of this separation is to observe the behavior of the communication of the community in the disaster areas. 
Finally, using the date and time of tweets, researchers categorize information into three categories including; during the disaster, one day after the disaster, and the next day. This is done with the aim to see the difference in communication behavior of the disasters during the disaster and the following days.

\section{Disaster Profile}

Researchers take tweet data in three flooded locations namely, Flood in Bandung, Flood in Sumedang and Banjir in Garut regency. The selection of the three disaster sites are based on the severity of the disaster. Here is the profile of each disaster.

\section{Flood in Garut}

The rain that fell within 4 hours on September 20, 2016, in Garut regency has caused overflow the Cimanuk River and Cikamuri River. Heavy rain caused flash floods in the Garut regency. The flood that came with the mud lunged at 22:00 pm, so that some people were already sleeping. This flash flood hit 6 districts of Kota Garut, Bayongbong, Karangpawitan, Taraging Kidul, Taragong Kaler, and Banyuresmi. In addition to the high rainfall, flood floods occur because the Cimanuk river basin is in critical condition. This is exacerbated by a narrowing and silting of the river (BBC, 2016).

The flood also hit people's houses on the banks of the river. The status of the emergency response took effect until September 27th, 2016. As of that date, 19 people were still missing. In addition, there were still many public facilities that had were not functioning. Thus, the status of emergency response was extended until October 4th, 2016. Emergency status was enacted to facilitate the deployment of resources, to speed up the search, rescue, and evacuation of victims (BBC, 2016).

As reported by BNPB, (2016), this flood caused the death of 34 people, and 19 people lost. In addition, it was noted that 35 people suffered injuries. The number of displaced people was 6,361 people. Mud and flood material caused difficulties for the team in searching for victims, so not all victims could be found. Another impact of this flood was damage to homes and public facilities. In more detail, more than 1700 houses were damaged, from minor to moderate damage. Public facilities damaged were hospitals, schools and places of worship. More than 40 schools were damaged, causing about two thousand students, not in school. In addition to this, flood damage also resulted in 15 facilities worship damaged.

\section{Flood in Sumedang}

Landslide and flood hit Sumedang Regency on September 20th, 2016. At least, eight landslide cliffs hoard the BandungCirebon Highway, precisely in the vicinity of Cadaspangeran, Sumedang Selatan District, Sumedang District. The point of landslide spread in Anjung, Cimareme, Ciherang, Pasirucing, Samoja, Sumedang Selatan. As a result, the traffic flow was totally paralyzed due to roads buried in landslides (Tribunnews, 2016).

Reported by BNPB (2016), the landslide was also piled houses in Cimareme, Pasanggrahan Baru Village, Sumedang Selatan Subdistrict. Two people were found dead, and a person was suspected to be buried by avalanches. While in the Village, Baginda, South Sumedang, landslide piled up one house residents, one person was successfully evacuated in a state of death. Meanwhile, the 1.6-meter-high floods soaked six houses in Puyuh Mountain Village, Sukajaya Village, Sumedang Selatan District. As a result, 6 families were evacuated from their homes. In addition, 1500 people were suffering, and 1220 people were evacuated.

\section{Flood in Bandung}

On October 24, 2016, Bandung was hit 
by rain for two hours, from 11.30 to 13.30 . The rain caused floods that reached more than one meter high. The worst flood point was in Pasteur region. The high and rapid flow of the floods caused some vehicles to drift away (Tempo, 2016).

Based on the BNPB report (2016), floods caused hundreds of homes to be submerged. Some houses were damaged by eroded floods on the banks of Cilimus River. Flooding also damaged one educational facility. This flood also caused a person died. Moreover, a health facility was also reported broken by this flood

\section{Findings}

The first research question in this paper focuses on the use of social media by users in the disaster area. In the three case studies presented, the data show that the three most frequently shared information tweeted by Twitter users in the disaster area include: disaster event reports, based on user perspective, coordination of rescue efforts, and condolences. For the category of disaster report from the user's perspective, the highest percentage was found in the City of Bandung with $77 \%$ tweet used in this category, followed by Sumedang Regency with 36\% percentage. The lowest percentage is occupied by Garut Regency which is only 1\% adrift of Sumedang Regency, which is $36 \%$.

The second most used social media function in the disaster area is coordinating rescue efforts. The results showed that $36 \%$ tweets were collected in Garut Regency used to coordinate rescue efforts. In Sumedang District, we found $34 \%$ of tweets were used to perform this function. Lastly, in the City of Bandung, there are only 3\% tweets from netizens who use this function.

In the category of the expression of condolence that ranks third. In Sumedang District we found $17 \%$ of the total number of tweets gathered discussed about this function. Meanwhile, in Garut 14\% tweet is talking about this information. Finally, in Bandung, this function is only used $4 \%$.

Second-hand reporting in three case studies is not used singly. Overall, only 3\% of netizens in these three regions use twitter to provide secondhand reports. In addition, requests for assistance are also not widely used by netizens in the disaster area. Only $3 \%$ of netizens in disaster areas use this function. Furthermore, the function of providing counseling and health assistance is used by $3 \%$ in all three areas. People in the disaster areas rarely use twitter to criticize disaster management efforts by the government. This is due to the findings of the research, showing that only $1 \%$ of users in Bandung are talking about this function. In the other two cities, this category is not found. The last is the use of the function of social media to discuss the cause of the disaster. This function is used $2 \%$ by people in Bandung. Meanwhile, this function is not found in the case of floods in Sumedang and Garut regencies.

To sum it up, Table 3 explains that generally, there are three information which are often shared by netizens in the affected area, such as disaster report from users' perspective, coordinating relief effort, and express the sympathy. The highest level, is the disaster report from users' perspective, which reaches $49 \%$ from the whole tweets collected. Generally, tweets in this category are about weather report, and up-to-date condition in the disaster area. The second place is coordinating relief report, with the percentage of $24 \%$ from the total data. In this category, netizens used these tweets to collect and distribute help from the people. The last is expressing sympathy, with the percentage of $11 \%$. In this category, netizens usually pray and hope that the disaster ends. In addition, some other social media functions that are used, but not very significantly include, secondhand reporting, assistance requests, providing counseling and medical assistance, criticizing the government, and discussing the causes of disasters. 
Table 3.

Shared Information by Netizens in affected Area

\begin{tabular}{lcccc}
\hline \multicolumn{1}{c}{ Category } & Sumedang & Bandung & Garut & Total \\
\hline Report of disaster from users' perspective & $36 \%$ & $77 \%$ & $35 \%$ & $49 \%$ \\
Disaster report (secondhand reporting) & $2 \%$ & $1 \%$ & $5 \%$ & $3 \%$ \\
Demand for help & $1 \%$ & $2 \%$ & $2 \%$ & $2 \%$ \\
Coordinating relief effort & $34 \%$ & $3 \%$ & $36 \%$ & $24 \%$ \\
Providing counseling and help of health and mental & $5 \%$ & $0 \%$ & $4 \%$ & $3 \%$ \\
Criticizing government & $0 \%$ & $1 \%$ & $0 \%$ & $0 \%$ \\
Expressing the sympathy & $17 \%$ & $4 \%$ & $14 \%$ & $11 \%$ \\
Discussing the cause of disaster & $0 \%$ & $2 \%$ & $0 \%$ & $1 \%$ \\
Misc. & $6 \%$ & $11 \%$ & $2 \%$ & $6 \%$ \\
\hline Total & $\mathbf{2 7 6}$ & $\mathbf{3 5 1}$ & $\mathbf{4 8 0}$ & $\mathbf{9 7 0}$ \\
\hline
\end{tabular}

Source: Research results

By seeing twitter bio, the writers try to identify kind of users. So far, five types of users participate in disaster. The users are as follow: society, government, media, celebrity, and journalist. The result of the research shows that users are dominated by local people, with the percentage of $96 \%$. Other than that, there are media with $3 \%$. Medias who participate are local medias of radio or local news organization.

Table 4.

Users in Affected Area of Disaster

\begin{tabular}{ccccc}
\hline User & Sumedang & Bandung & Garut & Total \\
\hline Society & $100 \%$ & $95 \%$ & $94 \%$ & $96 \%$ \\
Government & $0 \%$ & $1 \%$ & $0 \%$ & $0 \%$ \\
Media & $0 \%$ & $4 \%$ & $5 \%$ & $3 \%$ \\
Celebrity & $0 \%$ & $1 \%$ & $0 \%$ & $0 \%$ \\
Jurnalist & $0 \%$ & $0 \%$ & $1 \%$ & $0 \%$ \\
\hline Total & 120 & 370 & 480 & 970 \\
\hline
\end{tabular}

Source: Research results

Table 4 shows the users who participated in the use of Twitter in the disaster area. In all the three case studies, we found that users were dominated by the lay people. In Sumedang District, we found that the overall Twitter users in the disaster area were lay people, while in the city of Bandung $95 \%$ of the user is the lay people. Then, in the District of Garut, we found that $84 \%$ of the users were lay people.

We also find the participation of 'local media,' such as local radio and local newspapers. In the city of Bandung, we found $1 \%$ of users are the media, while in Garut district, 5\% of users is the media. Other actors exist, but the numbers are not significant; among others, the government, celebrity, and journalists. We also find the absence of some users in social media. In the district of Sumedang, we did not find the presence of government, media, celebrity, and journalists in the disaster area. Meanwhile, in Bandung, we did not find any journalists. Finally, In Garut district we did not find the presence of government, celebrity, and journalist in the disaster area.

This study also shows the behavior of social media, use by lay people in disaster areas, that is presented in Table 5. We found that in Sumedang District, the function of social media is more widely used by clay people to report disaster events from the user's perspective. This function is found in $36 \%$ tweets. Different $2 \%$ with the previous function, coordinating relief effort ranks second, found as much as $34 \%$. The last is the expression of sadness that ranks last. This category is found in $17 \%$ tweets of the entire tweet.

In the City of Bandung, most of the lay people use Twitter to provide reports on disaster situations from their perspective. A total of $71 \%$ of tweets we found, which were used for this category. Furthermore, $3 \%$ of users use Twitter to express sympathy and pray for disaster not to recur, and victims are given safety. Lastly, $1 \%$ tweet is used to coordinate 
Table 5.

Shared Information from Society in affected disaster area

\begin{tabular}{lllll}
\hline \multicolumn{1}{c}{ Category } & Sumedang & Bandung & Garut & \multicolumn{1}{c}{ Total } \\
\hline Report of disaster from users' perspective & $36 \%$ & $75 \%$ & $33 \%$ & $48 \%$ \\
Coordinating relief effort & $34 \%$ & $1 \%$ & $34 \%$ & $2 \%$ \\
Expressing the Sympathy & $17 \%$ & $3 \%$ & $14 \%$ & $11 \%$ \\
\hline
\end{tabular}

Source: Research results

rescue efforts. In Garut District, the majority of information shared by users is a disaster report from a user's perspective. A total of $11 \%$ of tweets were used for the category of the expression of condolences. The last category is the coordination of rescue efforts found as much as $2 \%$ of the total tweets. This is because the numbers are not significant, the writer just engages the lay people to look for information they shared during the disaster. The result of the research showed that the overall society lay persons in the disaster area, sharing disaster report from users' perspective with the percentage of $43 \%$. The second place is coordinating relief effort with the percentage of $23 \%$. The last is expressing sympathy with the percentage of $11 \%$.

Table 6, shows the use of Twitter during the disaster, the day after the disaster occurred and the next day. The first day of the floods in Bandung, 17\% tweets contains information about the report of the disaster from the user's perspective. The number increased to $37 \%$ on the second day and fell to $23 \%$ on the next day. The use of Twitter to coordinate rescue efforts was only found on the first day of the disaster, and was not found on other days. Lastly, the use of Twitter to express sympathy, on the first and second day is used $1 \%$. The total number increases to $2 \%$ in the next day.

In Sumedang District, Twitter on the first day is more used to provide disaster reports and express sympathy, used 3\% for each category. In this case, we found $1 \%$ of tweets used to coordinate rescue efforts. On the second day, tweet to give disaster report from user's perspective is equal to tweet to express sympathy, used 3\% for each category. Then, find that tweet to coordinate the rescue efforts used as much as $5 \%$. On the next day, tweets for coordinating the efforts of the rescue of the victims, and reporting the disaster from the perspective of users have the same number of $30 \%$. The rest is the tweet to express the sympathy used $9 \%$.

The first day of the floods in Sumedang district, the users use Twitter to report disaster situations from the users' perspective. On the same day, we did not find the use of Twitter to coordinate rescue efforts, or express sympathy. The next day, the use of Twitter for each category increased. On the second day, the use of Twitter to report disaster events from the perspective of users found $10 \%$. Then, we found $3 \%$ tweets are tweeted to express condolences. In addition, the use of Twitter to coordinate rescue efforts used $3 \%$. The number of tweets also increased from the second day to the next day. The use of Twitter for disaster reports from the user's perspective was found $41 \%$ of the total tweets. Then, the use of Twitter to express the condolences is found as much as $20 \%$. Finally, the use of Twitter for the rescue coordination effort was found $18 \%$.

By considering the time of Twitter usage, writers try to identify if there is different information, which has been shared each day. The result of the research shows in the first day of the disaster; users tend to use Twitter to report the incident of the disaster. Then, the information increases the day after. Twitter usage for coordinating relief effort in the first day, the percentage is not significant, but it will increase for the day after. Likewise, the 
Table 6.

Shared information based on usage time

\begin{tabular}{|c|c|c|c|c|c|c|c|c|c|c|c|c|}
\hline \multirow[b]{2}{*}{ Category } & \multicolumn{3}{|c|}{ Bandung } & \multicolumn{3}{|c|}{ Garut } & \multicolumn{3}{|c|}{ Sumedang } & \multicolumn{3}{|c|}{ Total } \\
\hline & مَ & 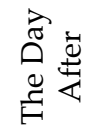 & 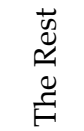 & مَّ & 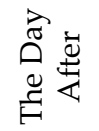 & 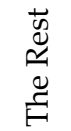 & مُ:ٌ & 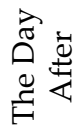 & 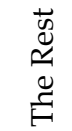 & مُ & 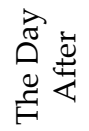 & 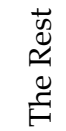 \\
\hline from users' perspective & $17 \%$ & $37 \%$ & $23 \%$ & $3 \%$ & $3 \%$ & $30 \%$ & $1 \%$ & $10 \%$ & $41 \%$ & $7 \%$ & $17 \%$ & $31 \%$ \\
\hline Coordinating relief effort & $3 \%$ & $0 \%$ & $0 \%$ & $1 \%$ & $5 \%$ & $30 \%$ & $0 \%$ & $3 \%$ & $18 \%$ & $1 \%$ & $3 \%$ & $16 \%$ \\
\hline Expressing sympathy & $1 \%$ & $1 \%$ & $2 \%$ & $3 \%$ & $3 \%$ & $9 \%$ & $0 \%$ & $7 \%$ & $20 \%$ & $1 \%$ & $3 \%$ & $10 \%$ \\
\hline
\end{tabular}

Source: Research results

tweet usage to express sympathy, even though the numbers are not significant, but it keeps increasing every day.

\section{Discussion}

The research provides an empiric depiction of social media usage, from netizens in the affected disaster area. This research used category which was made by Takahashi et al., (2015). This research also tried to observe characteristic based on users' category (society, government, journalist, celebrity, and media) and the time of the usage (during the disaster and the days after). The result of the research showed that Twitter users in the affected disaster area, tend to use Twitter to report the accident of the disaster from users' perspective, coordinating relief effort and expressed sympathy. The result of the research is in line with the function of social media, which enable the users to create content and connect with other users (Blank and Reisdorf, 2012). Users can use the feature they have, to document and share information about the disaster, even when professional media and journalist are not in that event (Meikle and Redden, 2011). This research also confirms the finding of Alexander (2014), that social media can be used to monitor disaster situation. The finding in this research is not the same with the research of Takahashi et al., (2015). That researcher found that users in the disaster location tend to share secondhand information. It is because of Takahashi et al., (2015) used location in profile, to categorize disaster location; whereas this research used geolocation feature of Twitter.

Besides the sharing of the disaster information, Twitter users in the disaster location use Twitter to coordinate relief effort, which content of tweet to receive and distribute help, to the disaster victims. The result of the research is in line with the finding of Takahashi et al., (2015), which found that Twitter usage for coordinating relief effort was in second place after the secondhand report. Moreover, this result is also in line with Hughes \& Palen, (2009) who found that users use social media to help recovery activities. The most shared information by users in the disaster area is memorialized about prayer and condolences, and hope that victims are given fortitude. Alexander, (2014) reveals that social media can be used to make people sympathy in certain things. People who are in disaster location feel that they are supported to face the future (Taylor et al., 2012).

In this study, the researcher also lays one of the focuses to laypersons in the affected disaster area, to learn the communication behavior during the disaster. Takahashi et al. (2015) explains that they are often excluded from social media research in disaster. Even when Alexander, (2014) finds that social media shows disaster location, people often dominate disaster communication, rather than other users, such as government, media, and journalist. People try to report disaster to other society. The result of this research is not suitable with the findings of Takahashi et al. (2015) that layperson tends to show grief expression, and hope through twitter, this research finds that layperson tends to report 
disaster situation, which then proves that users through their gadget make and consume the content (Meikle and Redden, 2011).

From the aspect of time, this research finds that tweet for people in the disaster location; the numbers are increasing. It is suitable with the finding of Amanda L Hughes, Palen, Sutton, Liu, \& Vieweg (2008) who found that social media will be used after the disaster, as a way to help disaster victims. This research is not the same as Binder (2012) findings which observed that Twitter usage is not related to time. In contrast, this research finds that numbers of tweets will increase from time to time.

\section{Conclusion}

This research gives depiction about behavior communication for people in the disaster-affected area, through social media. By using a framework made by Takahashi et al. (2015), this research finds that people in the disaster location use twitter to give first-hand report, coordinate rescue effort and give help and express the grief. Then, the result of this research shows that by using geolocation, the depiction of Twitter usage is clearer than for bordering the location. By focusing on the affected area, Twitter used by lay people is usually found rather than other users. From the segment of time, the researcher finds a number of tweets that will increase each day. Users will share more information the days after rather than the day of disaster. The researcher is certain, that by observing the tweets which are from the disaster-affected area, it will result in a clearer information by not bordering data location.

This research also has some limitations. Researcher only focuses on 3 locations. The further researcher may be able to add location to get more data. Second, researcher neglects that local language that maybe it is still used on twitter. Yet, the researcher tries to use keywords to represent disaster communication in the affected area. Then, researcher can engage local language to collect more data.

\section{References}

Acar, A., \& Muraki, Y. (2011). Twitter for crisis communication: lessons learned from Japan's tsunami disaster. International Journal of Web Based Communities, 7(3), 392. doi: 10.1504/IJWBC.2011.041206

Alexander, D. E. (2014). Social Media in Disaster Risk Reduction and Crisis Management. Science and Engineering Ethics, 20(3), 717733. doi: 10.1007/s11948-013-9502-z

BBC. (2016). Banjir di Garut: Belasan tewas, sejumlah orang hilang. Retrieved from http://www.bbc.com/indonesia/berita indonesia/2016/09/160921_indonesia_ banjir_garut.

Binder, A. R. (2012). Figuring out \#fukushima: An initial look at functions and content of US twitter commentary about nuclear risk. Environmental Communication, 6(2), 268-277. doi: 10.1080/17524032.2012.672442

Blank, G., \& Reisdorf, B. C. (2012). The participatory web: A user perspective on Web 2.0. Information Communication and Society, 15(4), 537-554. doi: 10.1080/1369118X.2012.665935

BNPB. (2016). Data dan Informasi Bencana Indonesia. Retrieved from http://dibi. bnpb.go.id/.

Fraustino, J. D., Liu, B., \& Yan, J. (2012). Social media use during disasters: a review of the knowledge base and gaps. National Consortium for the Study of Terrorism and Responses to Terrorism. University of Maryland: 1-39.

Houston, J. (2012). Public disaster mental/ behavioral health communication: Intervention across disaster phases. Journal of Emergency Management, 10(4), 283-292. doi: 10.5055/jem.2012.0106 
Houston, J. B., Hawthorne, J., Perreault, M. F., Park, E. H., Hode, M. G., Halliwell, M. R., McGowen, S. E. T., Davis, R., Vaid, S., McElderry, J. a, \& Griffith, S. a (2014). Social media and disasters: a functional framework for social media use in disaster planning, response, and research. Disasters, 39(1), 1-22. doi: 10.1111/disa.12092

Hughes, A. L., \& Palen, L. (2009). Twitter adoption and use in mass convergence and emergency events. International Journal of Emergency Management, 6(3/4), 248-260. doi: 10.1504/IJEM.2009.031564.

Hughes, A. L., Palen, L., Sutton, J., Liu, S. B., \& Vieweg, S. (2008). "Site-Seeing" in disaster: An examination of on-line social convergence. $5^{\text {th }}$ International ISCRAM Conference. Beijing, China: 44-54.

Meikle, G., \&Redden, G. (2011). Introduction: transformation and continuity. In G. Meikle \& G. Redden(Eds.). News Online: Transformations and Communities (pp. 1-19). New York: Palgrave Macmillan Education.

Miyabe, M., Miura, A., \& Aramaki, E. (2012). Use trend analysis of twitter after the great east japan earthquake. Conference on computer supported cooperative work companion. Seattle: 175-178. doi: 10.1145/2141512.2141571.

Muralidharan, S., Dillistone, K., \& Shin, J. H. (2011). The Gulf Coast oil spill: Extending the theory of image restoration discourse to the realm of social media and beyond petroleum. Public Relations Review, 37(3), 226-232. doi: 10.1016/j.pubrev.2011.04.006

Murthy, D., \& Longwell, S. A. (2013). TWITTER AND DISASTERS: The uses of Twitter during the 2010 Pakistan floods. Information Communication and Society, 16(6), 837-855. doi: 10.1080/1369118X.2012.696123

Rodríguez, H., Díaz, W., Santos, J., \& Aguirre, B. (2007). Communicating Risk and Uncertainty: Science, Technology, and Disasters at the Crossroads. In Rodríguez, H., Quarantelli, E., \& Dynes, R. (Eds.), Handbook of Disaster Research (pp. 476-488). New York: Springer.

Shklovski, I., Palen, L., \& Sutton, J. (2008).
Finding Community Through Information and Communication Technology During Disaster Events. ACM Conference on Computer Supported Cooperative Work. San Diego, CA, USA: 127-136. doi: 10.1145/1460563.1460584

Smith, B. G. (2010). Socially distributing public relations: Twitter, Haiti, and interactivity in social media. Public Relations Review, 36(4), 329-335. doi: 10.1016/j.pubrev.2010.08.005

Starbird, K., \& Palen, L. (2010). Pass it on?: Retweeting in mass emergency. Proceedings of the $7^{\text {th }}$ International ISCRAM Conference. Seattle: 7. doi: 10.1111/j.15564029.2009.01231.x.

Takahashi, B., Tandoc, E. C. and Carmichael, C. (2015). Communicating on Twitter during a disaster: An analysis of tweets during Typhoon Haiyan in the Philippines. Computers in Human Behavior, 50, 392-398. doi: 10.1016/j.chb.2015.04.020

Taylor, B. M., Wells, G., Howell, G., \& Raphael, B. (2012). The role of social media as psychological first aid as a support to community resilience building. The Australian Journal of Emergency Management, 27(1), 20-26.

Tempo. (2016). Banjir Bandung: Seorang Pria Tewas, Pasteur Bisa Dilalui. Retrieved from https://nasional.tempo.co/read/814688/ banjir-bandung-seorang-pria-tewaspasteur-bisa-dilalui.

Tribunnews. (2016). Longsor dan Banjir di Sumedang, Lima Orang Dilaporkan Tewas. Retrieved from http://www. tribunnews.com/regional/2016/09/21/ longsor-dan-banjir-di-sumedang-limaorang-dilaporkan-tewas

Vieweg, S., Hughes, A. L., Starbird, K., \& Palen, L. (2010). Microblogging During Two Natural Hazards Events: What Twitter May Contribute to Situational Awareness. Proceedings of the $28^{\text {th }}$ international conference on Human factors in computing systems. Atlanta, GEorgia, USA: 1079-1088. doi: 10.1145/1753326.1753486.

Wahlberg, A. A. F., Lennart, S. (2014). Risk perception and the media. Journal of Risk Research, 3(1), 231-50. 